\title{
Immunophenotypic analysis of childhood Burkitt's lymphoma in the West Midlands 1957-1986
}

\author{
T J Jones, N A G Coad, K R Muir, S E Parkes, C D Evans, J R Mann
}

\author{
Department of \\ Histopathology, Royal \\ Shrewsbury Hospital, \\ Shrewsbury, \\ Shropshire \\ T J Jones \\ Department of \\ Paediatrics, \\ Walsgrave Hospital, \\ Coventry \\ N A G Coad \\ West Midlands \\ Regional Children's \\ Tumour Research \\ Group, The \\ Children's Hospital, \\ Birmingham \\ K R Muir \\ S E Parkes \\ Department of \\ Pathology \\ C D Evans \\ Department of \\ Oncology \\ J R Mann \\ Correspondence to: \\ Dr T J Jones, Department of \\ Histopathology, Royal \\ Shrewsbury Hospital, \\ Mytton Oak Road, \\ Shrewsbury SY3 8XQ \\ Accepted for publication \\ 7 June 1994
}

\begin{abstract}
Aims-To analyse the immunophenotype of a large number of non-endemic Burkitt's lymphomas to determine whether a B cell phenotype is consistently recognisable using formalin fixed, paraffin wax embedded archival material and a standard panel of commercially available antibodies.

Methods-Archival material was obtained from 30 cases of childhood Burkitt's lymphoma registered with the West Midlands Regional Children's Tumour Research Group. These were analysed by a standard avidin biotin complex immunoperoxidase method using antibodies to CD45, CD43, CD30, CD20, CD15, and immunoglobulin heavy and light chains.

Results-There was a high incidence of the CD45RB and CD20 immunophenotypes, with a clearly recognisable $B$ cell lineage even in archival material. IgM was identifiable in 13 of the $23(56 \cdot 5 \%)$ cases tested. Only three of $17(18 \%)$ cases expressed CD30. Positive membrane staining with CD45RO was observed in two $(6 \cdot 7 \%)$ cases.

Conclusions-A B cell lineage can be identified in Burkitt's lymphoma in formalin fixed, paraffin wax embedded material, even in archival tissue. There was a low incidence of membrane staining with CD45RO which is a potential source of diagnostic confusion.

(F Clin Pathol 1995;48:22-25)
\end{abstract}

Keywords: Burkitt's lymphoma, immunophenotypic analysis, B cell phenotype.

Table 1 Antibodies used to determine the immunophenotype in paraffin wax embedded material

\begin{tabular}{|c|c|c|c|}
\hline Antibody & Lymphoid specificity & Source & $\begin{array}{l}\text { Antigen } \\
\text { molecular } \\
\text { weight }\end{array}$ \\
\hline $\begin{array}{l}\mathrm{PD} 7 / 26(\mathrm{CD} 45 \mathrm{RB}) \\
\mathrm{MB1}(\mathrm{CD} 45 \mathrm{R}) \\
\mathrm{MB} 2\end{array}$ & $\begin{array}{l}\text { Leucocyte common } \\
\text { Mainly B cells } \\
\text { B cells, some macrophages and }\end{array}$ & $\begin{array}{l}\text { Dr DY Mason } \\
\text { Eurodiagnostics }\end{array}$ & $\begin{array}{l}220,205,190 \\
200,110,100\end{array}$ \\
\hline $\begin{array}{l}\text { MT1 (CD43) } \\
\text { L26 (CD20) } \\
\text { 4KB5 (CD45R) } \\
\text { UCHL1 (CD45RO) } \\
\text { Kil (CD30) } \\
\text { LeuM1 (CD15) } \\
\text { IgG } \\
\text { IgA } \\
\text { IgM Light chain } \\
\lambda \\
\kappa\end{array}$ & $\begin{array}{l}\text { epithelia } \\
\text { T cells, some B cells, myeloid cells } \\
\text { B cells } \\
\text { B cells, some T cells } \\
\text { T cells, myeloid cells } \\
\text { Ki1 activation antigen } \\
\text { RS cells, myeloid and monocytic cells }\end{array}$ & $\begin{array}{l}\text { Eurodiagnostics } \\
\text { Eurodiagnostics } \\
\text { Dako } \\
\text { Dako } \\
\text { Dako } \\
\text { Dako } \\
\text { Dako } \\
\text { Dako } \\
\text { Dako } \\
\text { Dako } \\
\text { Dako } \\
\text { Dako }\end{array}$ & $\begin{array}{l}28 \\
190,110,100 \\
43,35,32 \\
220,205 \\
180 \\
110\end{array}$ \\
\hline
\end{tabular}
Source: Dr DY Mason, Oxford, UK; Eurodiagnostics, Solihull, UK; Dako, High Wycombe,
UK.
Burkitt's lymphoma was first described in Central Africa in 1958. ${ }^{1}$ Patients presented at a median age of 17 years with tumours principally affecting the jaw and abdomen. Since then, similar tumours have been described in Europe,${ }^{23}$ North America, ${ }^{4}$ the Middle East, ${ }^{5}$ and North Africa. ${ }^{6}$ Burkitt's lymphoma cells typically have round nuclei with three to five small basophilic nucleoli. A starry-sky pattern of tingible body macrophages amid sheets of tumour cells is also a characteristic feature. Tumours with an identical mode of presentation but with differing nuclear morphology with more pleomorphic nuclei and large, often central, nucleoli have been labelled Burkittlike or non-Burkitt's lymphoma. The relevance of this distinction has been disputed ${ }^{7-14}$ and for the purpose of this study, both Burkitt's and Burkitt-like (non-Burkitt's) lymphomas were analysed as a single group.

Immunophenotypic analysis of Burkitt's lymphoma has previously been carried out on either cell suspensions, cryostat sections, or using a limited antibody panel, ${ }^{71015-20}$ although more recent analyses have been performed on paraffin wax sections using a larger antibody series. ${ }^{21-26}$ Most of these studies have indicated that a B cell phenotype is present; childhood lymphomas, however, have not been as exhaustively studied, although there has been one study on endemic cases. ${ }^{27}$ Another study reported two Burkitt-like lymphomas with possible $\mathrm{T}$ cell phenotypes. ${ }^{28} \mathrm{~A}$ further study ${ }^{19}$ found a high incidence of the OKT10 marker in otherwise typical cases of Burkitt's lymphoma which also expressed immunoglobulin.

\section{Methods}

The West Midlands Regional Health Authority has a child population of roughly $1 \cdot 17$ million. Details of all cases of childhood malignancy diagnosed within this population since 1957 have been obtained by the West Midlands Regional Children's Tumour Research Group. Clinical data have been extracted from the patients' clinical records. The original biopsy specimen and any subsequent necropsy material were obtained. An ongoing review of all cases of Hodgkin's and non-Hodgkin's lymphoma registered by this group produced 30 cases of Burkitt-like and Burkitt's lymphoma.

Unstained paraffin wax sections were obtained either from the referring institution or from the files of the Children's Hospital, Birmingham, where a large number of the 
Table 2 Antibody reactivity

\begin{tabular}{llllllllll}
\hline & \multicolumn{1}{l}{ Antibody } & & & & & & & \\
\cline { 2 - 9 } & PD7/26 & $M B 1$ & $M B 2$ & $M T 1$ & UCHL1 & L26 & 4 4K5 & Ki1 & LeuM1 \\
\hline $\begin{array}{l}\text { No. tested } \\
\text { No. positive }\end{array}$ & 22 & 30 & 30 & 30 & 30 & 30 & 29 & 17 & 9 \\
$\begin{array}{l}\text { Per cent } \\
\text { positive }\end{array}$ & 91 & 60 & 63 & 30 & 6.67 & 93 & 41 & 18 & 0 \\
\hline
\end{tabular}

cases were diagnosed initially. These were stained with haematoxylin and eosin, periodic acid-Schiff (PAS), and the Gordon and Sweet stain. Stained sections $(2 \mu \mathrm{m})$ were available from the Children's Hospital cases. Children were diagnosed as having Burkitt's lymphoma if they had the following features: nuclear size less than that of the accompanying histiocytes, round nuclei, and three to five basophilic nucleoli. Cases diagnosed as having Burkittlike lymphoma were also included in this study.

The antibodies used are presented in table 1 . Paraffin wax embedded material was used in all instances as cryostat sections were not available because of the retrospective nature of the study. The sections were stained using a standard avidin biotin complex immunoperoxidase technique consisting of dewaxing, inhibition of endogenous peroxidase activity with hydrogen peroxide in methanol, incubation with $3 \%$ bovine serum albumin, and then with the primary marker. Sections were then incubated with biotinylated rabbit antimouse conjugate and avidin biotin complex followed by diaminobenzidine. A light Mayer's haematoxylin was used as the nuclear counterstain. Positive staining for each antibody was as previously described in a large series of adult lymphomas. ${ }^{29}$ In some cases insufficient material was available for the full range of antibodies to be used.

\section{Results}

The median age of the cases included in this study was eight years with an evenly distributed range of two to 14 years. Twenty five patients were male and five female.

The primary sites of the tumours were as follows: 23 intra-abdominal (nine ileal, four ileocaecal, four caecal, one in the mesenteric nodes, one mesentery, one ovary, one liver

Table 3 Immunoglobulin type

\begin{tabular}{lrrlll}
\hline & \multicolumn{7}{c}{ Immunoglobulin } \\
\cline { 2 - 6 } & $G$ & \multicolumn{1}{c}{$A$} & $M$ & \multicolumn{1}{c}{$\kappa$} & $\lambda$ \\
\hline No. tested & 19 & 11 & 23 & 22 & 19 \\
No. positive & 4 & 0 & 13 & 5 & 10 \\
Per cent positive & 21 & 0 & 56.5 & $22 \cdot 7$ & $52 \cdot 6$ \\
\hline
\end{tabular}

Table 4 Site of immunoglobulin expression

\begin{tabular}{llllll}
\hline & $G$ & $A$ & $M$ & $\kappa$ & $\lambda$ \\
\hline Membrane & 0 & 0 & 9 & 2 & 2 \\
Cytoplasmic & 0 & 0 & 1 & 1 & 4 \\
Both & 4 & 0 & 3 & 2 & 4 \\
\hline
\end{tabular}

$\operatorname{IgM} \kappa$ 4; IgM $\lambda$ 5; IgG $\kappa 2 ; \operatorname{IgG} \lambda 1$. and pancreas, and not stated in two cases); two peripheral lymph node based (one cervical and one axillary); two tonsillar; one in the postnasal space; one in the right lobe of thyroid, and one mandible.

The results obtained and the antibody panel used are presented in tables 2,3 , and 4 .
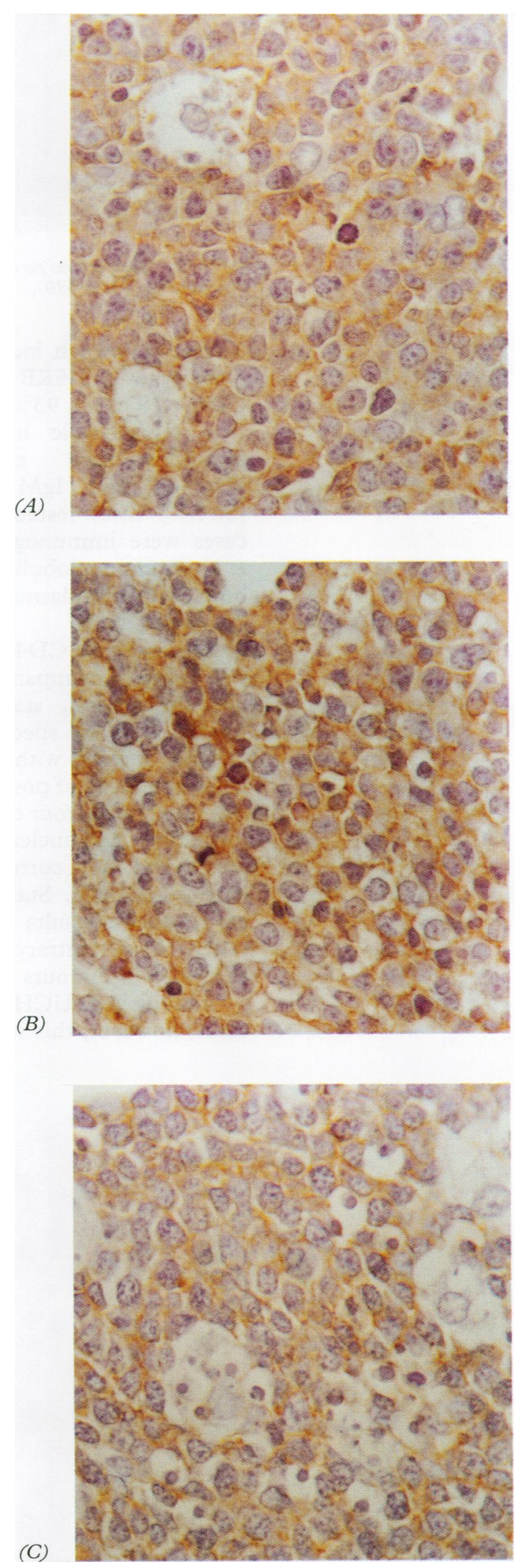

Figure 1 Immunophenotype in Burkitt's lymphoma. On staining, there was a high incidence of the following immunophenotypes: (A) CD45RB (PD7/26); (B) CD20 (L26); and (C) CD45R (MB1) (all $\times 630)$. 


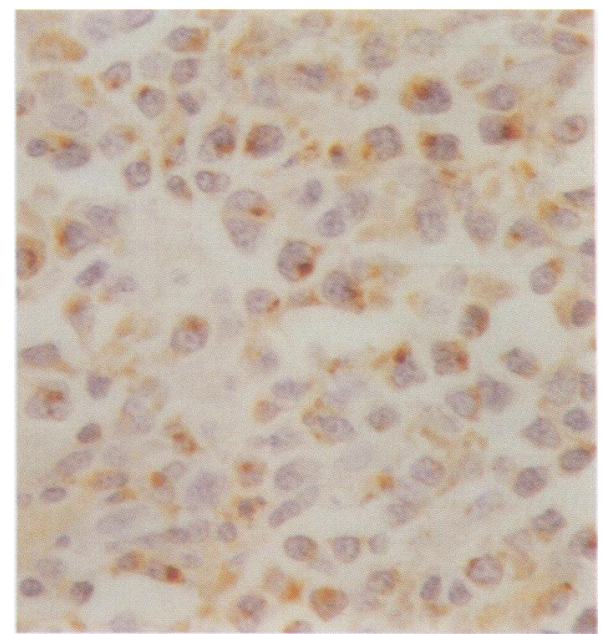

Figure 2 Conspicuous perinuclear cytoplasmic dot positivity (MB2; × 630).

There was a high incidence of the immunophenotype CD45RB (20 of 22; 91\%) and CD20 (28 of 30 ; 93\%) with the B cell phenotype recognisable in most cases (fig 1). Immunoglobulin expression was also observed, with IgM present in 13 of 23 (56.5\%) cases tested. Both CD20 negative cases were immunoglobulin positive (IgG1, $\lambda$ 1). Immunoglobulin was expressed within both the cytoplasmic membrane and the cytoplasm itself.

Expression of CD45R recognised by $4 \mathrm{~KB} 5$ was always accompanied by staining for L26 and, in general, staining with $4 \mathrm{~KB} 5$ was weaker and less specific than that for L26. Overall, staining with $\mathrm{MB} 1$ and MB2 gave a similar number of positive results (18 and 19, respectively). In four cases MB2 staining had a distinctive paranuclear dot pattern (fig 2), which did not correlate with staining for immunoglobulin. Staining with Kil (CD30) gave positive results in three of 17 sections tested; this is contrary to the results previously described in tumours from endemic areas. ${ }^{27}$

Staining with UCHL1 occurred in 18 of 30 cases; however, this was predominantly cyto-

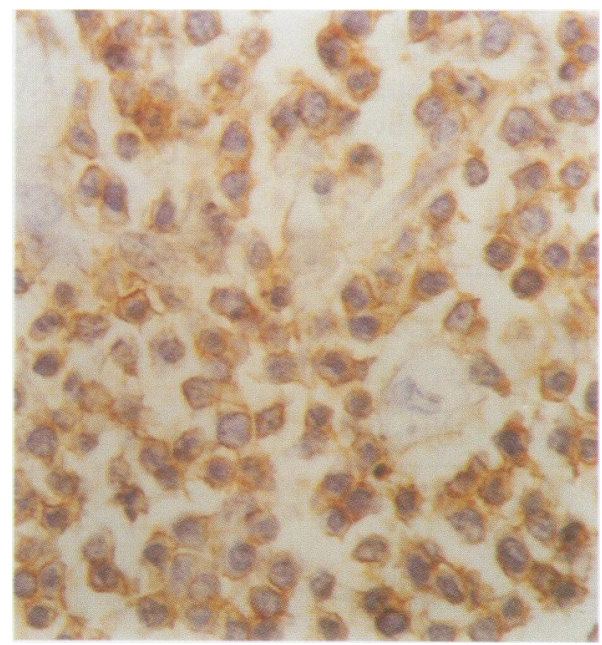

Figure 3 True membrane positivity, rather than nonspecific cytoplasmic reactivity, was present (CD45RO $(U C H L 1) \times 630)$. plasmic and non-specific, although in two cases membrane staining appeared to be present (fig 3 ). Interpretation of the staining pattern with this antibody was often hampered by autolysis caused by delay in fixation in the original specimen.

\section{Discussion}

In this study immunophenotypic analysis has shown a clear B cell lineage, identifiable on routinely processed material. Earlier studies using cell suspensions ${ }^{1015-17}$ highlighted the presence of surface immunoglobulin, mainly IgM. Other authors subsequently confirmed these findings using immunofluorescence ${ }^{20}$ and immunoperoxidase studies on cryostat sections. ${ }^{19}$ Using immunofluorescence, $82 \%$ of 114 biopsy specimens were IgM positive; with the immunoperoxidase technique, 16 of 18 cases expressed IgM, with 13 also positive for the $\lambda$ light chain. A more recent study has confirmed that a B cell immunophenotype can be recognised on paraffin wax sections of Burkitt's lymphoma, although smaller numbers were analysed. ${ }^{26}$

We have shown the presence of both membrane and cytoplasmic immunoglobulin in non-endemic Burkitt-like and Burkitt's lymphoma and confirmed that this is usually IgM, with a smaller number expressing IgG. We have also confirmed the high incidence of $\lambda$ light chain expression, which was present in 10 of 19 cases tested. The significance of this finding is uncertain but may be caused by a t8;22 translocation as the $\lambda$ gene is located on chromosome $22^{30}$; however, this translocation is present in only 5\% of Burkitt's lymphomas and therefore cannot be the complete explanation.

Studies on endemic cases show a similar high incidence of CD20 expression to that observed here. ${ }^{27}$

As yet, only one study has analysed the incidence of leucocyte common antigen (LCA) in Burkitt-like lymphoma compared with lymphoblastic lymphoma, the results of which showed consistent LCA expression in Burkitt-like lymphoma along with the expression of one or more $\mathrm{B}$ cell markers. ${ }^{24} \mathrm{~A}$ further study found a high incidence of $\mathrm{LN}-1$ and LN-2 expression in Burkitt-like and Burkitt's lymphoma sections fixed in B5. ${ }^{25}$

Another study ${ }^{19}$ has shown a high incidence of OKT10 in Burkitt's lymphoma, which was present in 14 of 17 cases on examination of cryostat sections; other authors ${ }^{28}$ have reported two cases with a possible $T$ cell phenotype. This study also used frozen material only and the morphology was different from that usually associated with Burkitt's lymphoma as high numbers of eosinophils and myelomonocytic cells were present; the Ki67 count in these cases was also lower than that usually found in Burkitt's lymphoma ( $<25 \%$ compared with $>80 \%$ ). In this study positive staining with UCHL1 was predominantly cytoplasmic and analysis was limited by autolysis; however, two cases showed true membrane staining as has been reported in other B cell lymphomas. ${ }^{22}$ 
The low incidence of CD30 staining in this study may be related to the poor correlation with Epstein-Barr virus in the non-endemic tumours ${ }^{3132}$; this antibody is strongly expressed in the African endemic type. ${ }^{27}$

In conclusion, we have shown that a B cell lineage can be identified in Burkitt-like and Burkitt's lymphoma, that there is a low incidence of membrane staining with UCHL1, and a higher incidence of non-specific cytoplasmic staining, which is a potential source of confusion.

We thank the West Midlands Regional Health Authority and the Special Trustees of the Former United Birmingham
Hospitals for financial support; Dr JAH Waterhouse, Ms C Hospitals for financial support; Dr JAH Waterhouse, Ms C
Roginsky and Mrs S Wilson for access to data in the Roginsky and Mrs $S$ Wilson for access to data in the
Birmingham and West Midlands Regional Cancer Registry, Birmingham and West Midlands Regional Cancer Registry, and Dr GJ Draper and Mr CA Stiller for access to data held by the Childhood Cancer Research Group. We also thank all consultant colleagues who provided the histological material without which this study would not have been possible, and numerous medical records officers, consultants, and general practitioners for access to patient records.

1 Burkitt D. A sarcoma involving the jaws in African children. Br $\mathcal{f}$ Surg 1958;46:218-23.

2 Philip T, Lenoir GM, Bryon PA, Gerard-Marchant R, Souillet G, Philippe M, et al. Burkitt-type lymphoma in France among non-Hodgkin's malignant lymphoma in Caucasian children. Br $\mathcal{f}$ Cancer 1982;45:670-8.

3 Wright DH. Burkitt's tumour in England: A comparison with childhood lymphosarcoma. Int $\mathcal{f}$ Cancer 1966;1: 503-14.

4 O'Conor GT, Rappaport H, Smith EB. Childhood lymphoma resembling "Burkitt's" tumour in the United States. Cancer 1965;18:411-17.

5 Annaissie E, Geha S, Allam C, Jabbour J, Khalyl M, Salem P. Burkitt's lymphoma in the Middle East. A study of 34 P. Burkitt's lymphoma in the $M$

6 Ladjaj Y, Philip T, Lenoir GM. Abdominal Burkitt's type lymphoma in Algeria. $\mathrm{Br} \mathcal{F}$ Cancer 1984;49:503-12.

7 Grogan TM, Warnke RA, Kaplan HS. A comparative study of Burkitt's and non-Burkitt's "undifferentiated" malignant lymphoma. Cancer 1982;49:1817-28.

8 Miliauskas JR, Berard CW, Young RC, Garvin AJ, Edwards BK, DeVita VT Jr. Undifferentiated nonHodgkin's lymphoma (Burkitt's and non-Burkitt's types). The relevance of making this distinction. Cancer 1982;50:2115-21.

9 Levine AM, Pavlova Z, Pockros AW, Parker JW, Teitelbaum AH, Paganini-Hill A, et al. Small nonTeitelbaum AH, Paganini-Hill A, et al. Small noncleaved follicular center cell lymphoma: Burkitt's and non-Burkitt variants in the United
features. Cancer 1983;52:1073-9.

10 Grogan TM, Warnke RA, Kaplan HS. A comparative study of Burkitt's and Non-Burkitt's lymphoma. Cancer 1982;49:1817-28.

11 Kelly DR, Nathwani BN, Griffith RC, Shuster J, Sullivan MP, Hvizdala E, et al. A morphologic study of childhood lymphoma of the undifferentiated type. The Pediatric lymphoma of the undifferentiated cancer 1987;59:1132-7.

12 Hutchison RE, Murphy SB, Fairclough DL, Shuster JJ, Sullivan MP, Link MP, et al. Diffuse small non-cleaved cell lymphoma in children, Burkitt's versus noncell lymphoma in children, Burkitt's type. Cancer 1989;64:23-8.

13 Wilson JF, Kjeldsberg CR, Sposto R, Jenkin RD, Chilcote $\mathrm{RR}$, Coccia $\mathrm{P}$, et al. The pathology of non-Hodgkin's lymphoma of childhood. II. Reproducibility and relevance of the histologic classification of "undifferentiated" lymphomas (Burkitt's versus non-Burkitt's). Human Pathol 1987;18:1008-14.

14 Wilson JC, Kjeldsberg CR, Sposto R, Jenkin RDT, Hammond GD. In childhood non-Hodgkin's lymphoma, classification of the "undifferentiated" lymphoma, classification of the "undifferentiated"
lymphomas into Burkitt's and non-Burkitt's is poorly reproducible and clinically irrelevant [abstract]. Lab Invest 1984;50:66-7A.

15 Mann RB, Jaffe ES, Braylan RC, Nanba K, Frank MM, Ziegler JL, et al. Non-endemic Burkitt's lymphoma. A B-cell tumour related to germinal centers. $N$ Engl $\mathcal{F}$ Med 1976;13:685-91.

16 Berard CW, Jaffe ES, Braylan RC, Mann RB, Nanba K. Immunologic aspects and pathology of the malignant lymphomas. Cancer 1978;42:911-21.

17 Pavlova Z, Parker JW, Taylor CR, Levine AM, Feinstein DI, Lukes RI. Small non-cleaved follicular center cell DI, Lukes RJ. Small non-cleaved follicular center cell lymphoma: Burkitt's and non-Burkitt's variants in the 1987;59:1892-902.

18 Payne CM, Grogan TM, Cromey DW, Bjore CG, Kerrigan DP. An ultra-structural morphometric and immunophenotypic evaluation of Burkitt's and Burkittlike lymphoma. Lab Invest 1987;57:200-18.

19 Garcia CF, Weiss LM, Warnke RA. Small non-cleaved cell lymphoma. An immunophenotypic study of 18 cases and comparison with large cell lymphoma. Human Pathol 1986;17:454-61.

20 Gunven P, Klein G, Klein E, Norin T, Singh S. Surface immunoglobulins on Burkitt's lymphoma biopsy cells from 91 patients. Int $f$ Cancer 1980;25:711-19.

from 91 patients. Int $\mathcal{F}$ Cancer 1980;25:711-19.
21 Norton AJ, Isaacson PG. Lymphoma phenotyping in formalin-fixed and paraffin wax-embedded tissue. I. Range of antibodies and staining patterns. Histopathology 1989;14:437-46.

22 Norton AJ, Isaacson PG. Lymphoma phenotyping in formalin-fixed and paraffin wax-embedded tissue. II. Profile of reactivity in various tumour types [review]. Histopathology 1989;14:557-79.

23 Hall PA, D'Ardenne AJ, Stansfeld AG. Paraffin section immunohistochemistry. 1. Non-Hodgkin's lymphoma. Histopathology 1988;13:149-60.

24 Van Eyken P, Wolf-Peters CD, Van den Oord J, Tricot G, Desmet V. Expression of leukocyte common antigen in lymphoblastic lymphoma and small non-cleaved undifferentiated non-Burkitt's lymphoma: an immunoundifferentiated non-Burkitt's lymphoma: an im

25 Brownell MD, Sheibani $\mathrm{K}$, Battifora $\mathrm{H}$, Winberg $\mathrm{CD}$ Rappaport $H$. Distinction between undifferentiated (small non-cleaved) and lymphoblastic lymphoma. $A m \mathfrak{F}$ Surg Pathol 1987;11:779-87.

26 Davison AM, McKinney PA, Bailey CC, Lewis I, Cartwright RA, O'Brien C. Childhood lymphoma in Yorkshire. $\mathcal{F}$ Clin Pathol 1992;45:130-4.

27 Griffin A, Norton AJ, Lucas S. Endemic African Burkitt's and Burkitt-like lymphoma-diagnostic aspects. Abstract Pathological Society of Great Britain and Ireland 1989; Jan: 158th meeting.

28 Oliver JD, Grogan TM, Payne CM, Spier C, Richter LC Rangel CS. Burkitt's-like lymphoma of T-cell type. Mod Pathol 1988;1:15-22.

29 Stansfeld AG, Diebold J, Noel H, Kapanci Y, Rilke F, Kelenyi G, et al. Updated Keil classification for lymphomas [letter]. Lancet 1988;i:292-3.

30 Lenoir GM, Preud'homme JL, Bernheim A, Berger R. Correlation between immunoglobulin light chain expression and variant translocation in Burkitt's lymphoma Nature 1982;298:474-6.

31 Levine PH, O'Conor GT, Berard CW. Antibodies to Epstein-Barr virus (EBV) in American patients with Burkitt's lymphoma. Cancer 1972;30:610-15.

32 Magrath IT, Freeman CB, Pizzo P, Gadek J, Jaffe E, Santaella M, et al. Characterisation of lymphomaderived cell lines: comparison of cell lines positive and negative for Epstein-Barr virus nuclear antigen. II. negative for Epstein-Barr virus nuclear antigen. 